\title{
Discipline and Bounding: The History and Sociology of Science as Seen through the Externalism- Internalism Debate
}

\section{Citation}

Shapin, Steven. 1992. Discipline and bounding: The history and sociology of science as seen through the externalism-internalism debate. History of Science 30: 333-369.

\section{Published Version}

http://www.shpltd.co.uk/hs.html

\section{Permanent link}

http://nrs.harvard.edu/urn-3:HUL.InstRepos:3425943

\section{Terms of Use}

This article was downloaded from Harvard University's DASH repository, and is made available under the terms and conditions applicable to Other Posted Material, as set forth at http:// nrs.harvard.edu/urn-3:HUL.InstRepos:dash.current.terms-of-use\#LAA

\section{Share Your Story}

The Harvard community has made this article openly available.

Please share how this access benefits you. Submit a story.

Accessibility 
Hist. Sci., xxx (1992)

\title{
DISCIPLINE AND BOUNDING: THE HISTORY AND SOCIOLOGY OF SCIENCE AS SEEN THROUGH THE EXTERNALISM-INTERNALISM DEBATE
}

\author{
Steven Shapin \\ University of California at San Diego
}

From the beginning of the Second World War to the ending of the Cold War no problematic so deeply shaped the academic history and sociology of science than that inscribed in talk of 'internalism' and 'externalism'. Insofar as empirical work was deemed relevant to developing an overall appreciation of the nature of science, its dynamics and its relations with social and cultural environments, that relevance was locally achieved by gestures at opposed 'internalist' and 'externalist' theories, orientations, domains, and accompanying historiographic baggage. Students were initiated into the history and sociology of science by being told about these genres and the present state of play. Graduates' early orientation to their fields was achieved through affiliation with one or other genre and camp of practitioners. Reviews of the state of the history and sociology of science were seemingly obligated to use 'internalism' and 'externalism' as expository structures. Nowadays, however, historians of science commonly tell each other and their students that their discipline has transcended, outgrown or resolved those debates, and that it is a sign of the maturity of the field that references to the 'internal' and the 'external' have become less common or at least less unselfconscious. When uttered at all, the terms are likely to be surrounded by quotes, air-quotes or tones of voice. If in the 1960 s the central problematic of the academic discipline known as the history of science was pointed to by reference to the 'internal' and the 'external', by the late 1980s such usages increasingly betrayed the amateur, the neophyte, the outsider, or the out of touch. Within a generation the discourse of 'internalism' and 'externalism' seems to have passed from the commonplace to the gauche.

I want to suggest that this trajectory never transmitted the appropriate intermediate stages. I do not think that the theories indicated by 'externalism' and 'internalism' were ever properly defined or described. I do not think that the virtues of any defensible and coherent construals of these theories were ever properly considered and assessed. I do not think that talk of external and internal (hereafter e/i) 'factors' was ever properly associated with the respective theories, nor that such talk was adequately defended in terms of relevant 
bodies of epistemology and social theory. That the history of science community is now well and truly bored with the e/i debate is evident. (When I told historian colleagues and friends that I was going to write something on externalism and internalism, there was much sighing and rolling of eyes.) Nevertheless, there is justification for one more try to get to grips with what these debates were about and might coherently have been about. Instead of clarifying and engaging with the problematic, I think that over the last ten or fifteen years we rather turned our backs on it and wished it away. Nor does some of the rhetoric used to dismiss the e/i problematic inspire great confidence in our collective ability to think systematically and reflectively about some of the fundamental assumptions and procedures of our field. I intend these notes not as a resolution of the e/i debates but as an encouragement to consider how one might now go about addressing the issue of cultural boundaries in scientific practice.

Moreover, the history of our engagements with this problematic offers a perspicuous way of taking stock of the disciplines of history and sociology of science over the past half century or so. The historical path traced by e/i talk cuts across some of the most contested and difficult science studies terrain. An overview can help assess just what we have achieved and what we only think we have achieved. As we enter the last years of the century that gave birth to our disciplines as academic practices, it is being increasingly asserted not just that $\mathrm{e} / \mathrm{i}$ theories are inadequate but that the very categories we have traditionally used to construct the relevant boundaries are analytically flawed. I want, therefore, to attempt a brief and highly schematic archaeology of e/i talk at a moment just before it may - possibly - completely disappear from our view.

This essay has four main parts. In the first, I sketch some aspects of the development of academic e/i speech - how we came to go on this way about the history and social relations of science. This survey prepares the ground for following analytic discussion and is not offered as definitive or complete. ${ }^{1}$ Secondly, I identify a series of imprecisions and uncertainties in the congeries of theories, orientations and practices swept up into e/i discourse. I suggest that none of these items was particularly well defined or defended and that the e/i debate (such as it was) was marked by widespread and troubling incoherence. I argue that some of the most pervasive speech about e/i can (and should) be seen as deeply at odds with cherished procedures in cultural history generally. Thirdly, I identify resources that might permit historians and sociologists to explore scientific boundaries without doing violence to authentically historical inquiry. And, finally, I discuss some apparent problems associated with two currently popular and otherwise valuable perspectives on cultural boundaries - historicism and the actor-network theory connected with the work of Bruno Latour. 


\section{I(a). AN ARCHAEOLOGY OF THE BORDER}

No doubt, speech about the intrinsic and the extrinsic is characteristic of a wide range of cultural practices and arguably of all. Bounding a practice is a way of defining what it is, of protecting it from unwanted interference and excluding unwanted participants, of telling practitioners how it is proper to behave within it and how that behaviour differs from ordinary conduct, and of distributing value across its borders. ${ }^{2}$ Practices that have not succeeded in making their boundary-discourse stick are unlikely to be recognizable as distinct entities within the general stream of cultural life. The practices of academic disciplines can be subsumed in this generalization, and the emergence or differentiation of new disciplines is often marked by great attention to the establishment and policing of conceptual and methodological boundaries. ${ }^{3}$ Accordingly, as I shall suggest later, the topic constituted by actors' erection and identification of cultural boundaries merits serious historical and sociological study. Boundary-work may properly be treated within a general functional account of institutionalization. As such, boundary-speech, including the vocabulary of 'extrinsic/instrinsic', can be analysed not simply as indications of how things are but also as instrumentalities actively used to maintain social and cultural realities, to shift them in some desired direction, to say 'good' and 'bad'.

Conservative theorists are particularly drawn to schemes identifying the boundaries of discrete cultures, traditions or practices: ethical and epistemic judgements make sense when rendered internally, none at all performed externally. ${ }^{4}$ Much Foucauldian work sees patterns of exclusion and inclusion, of "controlling and delimiting discourse", as systems making truth and power. ${ }^{5}$ Karl Mannheim famously sought to specify the proper ambit of the sociology of knowledge by distinguishing between intellectual elements which were "socially or existentially determined" and those which were "immanently determined". Existential determination of knowledge (Seinsverbundenheit des Wissens) was defined by opposition: "The existential determination of thought may be regarded as a demonstrated fact in those realms of thought in which we can show $(a)$ that the process of knowing does not actually develop historically in accordance with immanent laws, that it does not follow only from the 'nature of things' or from 'pure logical possibilities', and that it is not driven by an 'inner dialectic' [and] (b) [that] the influence of these existential factors on the concrete content of knowledge is of more than mere peripheral importance ... penetrat[ing] into their forms and content." Mannheim did indeed identify natural science as "largely detachable from the historical-social perspective of the investigator", but the protection of science was not nearly as prominent a feature of his work as is commonly assumed. ${ }^{6}$ So far as the sciences themselves 
are concerned, descriptive and normative speech roughly corresponding to the external and the internal probably can be discerned in every form of practice and as far back in time as you like. And if one can assume boundary-speech as pervasive in the subject-matter, it might be thought of no special interest to trace an analogous discourse in the science studies disciplines. So here I need to make a distinction between the mere existence of lexical items corresponding to $\mathrm{e} / \mathrm{i}$, on the one hand, and the institutionalization of such speech into allegedly distinct and ideologically charged ways of analysing the nature of science and its mode of change, on the other. When I refer to e/i in the history and sociology of science, it is generally to gestures of the latter sort that I refer: the '-isms' and associated locutions implicating the '-isms'.

I exclude systematic treatment of the philosophy of science at the outset. Current impressions notwithstanding, I do not think that philosophy has ever been a serious player in the e/ $\mathrm{i}$ game. The erection and protection of boundaries guarding science from 'social contamination' were not major issues for philosophy of science, even though many philosophers were, of course, greatly concerned to demarcate science from non-science. There was no great $\mathrm{e} / \mathrm{i}$ debate in philosophy of science because there never was a serious debate about the relations between science and its social context. The great tradition of the philosophy of science was simply founded on the assumption that science could be interpreted as if external, sociological and historically contextual considerations did not matter. That enterprise was securely institutionalized long before the claims of turbulent historians and sociologists came to philosophers' notice. Thus, philosophers of science did not consider they required anything like a theory of internalism. ${ }^{7}$ Of course, certain developments in the history and sociology of science since the 1960s elicited philosophical reaction which looked to some historians like a defence of internalism. Specifically, a few philosophers responded with alarm to Thomas Kuhn's Structure of scientific revolutions (1962) and the subsequent work of relativist 'Kuhnians', largely on the basis of the apparent threat posed by 'incommensurability' to rationalist and progressivist accounts of scientific change. And many social historians of science were, of course, deeply suspicious of the invocation of "internal history" in Imre Lakatos's 1970 apology for the "rational reconstruction" of the history of science. ${ }^{8}$ But, in the main, philosophy of science went on its own way, paying little attention to the naturalistic stories told by historians and sociologists, and, in turn, being widely ignored by them.

A more pertinent lineage for current usages traces back to the origins of academic sociology of science and, especially, to the setting from which Robert Merton's early work emerged in the 1930s. In another paper I briefly noted both the pervasiveness of e/i talk in Merton's 1938 Science, technology and society and the strict limits he placed upon the ability of external consider- 
ations to do more than affect the overall value placed on science in a given setting and the rates at which different scientific foci developed. ${ }^{9}$ Despite the causative role claimed for Puritan strands of religion, Merton was keen to assure readers that "Specific discoveries belong to the internal history of science and are largely independent of factors other than the purely scientific". The "internal history of science" was repeatedly adduced to show the proper limits of external sociological accounting. The argumentative context was precisely defined: an attempt to show both the real role of external factors while ensuring that too much significance was not claimed for them in theorizing scientific change. ${ }^{10}$ Although I would not be surprised to find myself corrected by a more diligent historian, I think Merton's early work is the first site in which the internal and external were systematically invoked as gestures towards theories (albeit informal ones) of social and cultural change in science: these aspects of scientific change were due to external/extrinsic factors, those to internal/intrinsic.

Merton's early usages seem to have been creatively adapted from those of his major sociology teacher at Harvard. Pitirim Sorokin was then developing an all-embracing theory of cultural coherence and change. He offered a typology of the main types of cultural systems - "sensate", "ideational", and "idealistic" or "mixed" - which purported to identify distinct logics of integration. In Sorokin's scheme the entities which possessed an inherent logical consistency, and which immanently expressed that logic in historical change, were not special sub-cultural practices like science, music, religion, or legal thinking but the overall cultural system in which the practices were integrated components. Sorokin's concern was therefore to display the autonomy and self-regulation of these systems whose "logic of function, change, and destiny" and whose determination resides largely "within the system itself, is inherent within it":

In this sense any inwardly integrated system is an autonomous, selfregulating, self-directing, or, if one prefers, 'equilibrated' unity. Its life course is set down in its essentials when the system is born.

One cannot, Sorokin insisted, "explain" anything interesting about such cultural systems by invoking "external conditions and reduc[ing] the explanation of the change in the system to this or that external factor". Important change was endogenously caused:

At a certain point of its history (slightly accelerated or retarded by the external circumstances) the cultural system must undergo its inwardly ordained change. When this begins, all the main components of the culture change. ${ }^{11}$

Note, however, that Sorokin was utterly unconcerned with boundaries 
between the natural sciences and other elements of the system, including religion and social thinking. To Sorokin, such demarcations were neither consequential nor ideologically interesting. If, as seems likely, Merton adapted aspects of his teacher's vocabulary, his creative contribution consisted partly in re-locating the domain of autonomy and self-direction from the cultural system as a whole to the particular sub-culture of science. For Sorokin, early modern religion and science were part of one logically integrated system. For Merton, one was to speak of the religious influence on science as an "external factor".

Looked at from the perspective of the 1950s and 1960s Merton's boundaryspeech may have seemed self-evident: how else could one possibly conceive of the relations between science and its context? Nevertheless, it is striking how little the history of science produced in the period before, roughly, the mid1950 s was marked by attention to such boundaries and associated theories of scientific change. ${ }^{12}$ In the main, historians appear to have adopted a rather relaxed and matter-of-fact posture towards the role of external and internal factors (infrequently even using the locutions), while undeniably writing as if science was a self-contained and self-regulating system of ideas. In 1936 George Sarton - who co-supervised Merton's research at Harvard - blandly noted that "no doubt ... mathematical discoveries are conditioned by outside events of every kind, political, economic, scientific, military, and by the incessant demands of the arts of peace and war. ... However, we think that those events were only some of the factors among others, factors the power of which might vary and did vary from time to time."13 Beyond that, the founding father of American history of science was evidently not greatly interested in policing scientific boundaries.

Marxist historians and sociologists from the 1930s constituted a barely audible minority voice, though Merton took care to position his thesis between what he saw as the extremes of pure Weberian idealism and the strong materialism that first surfaced in Anglo-American consciousness with Boris Hessen's 1931 account of Newton's Principia. ${ }^{14}$ The nature and impact of British Marxist historiography has been admirably summarized elsewhere and I do not need to go over familiar ground. ${ }^{15}$ Just a few points may be stressed here. Firstly, it is noteworthy how little that sort of work was attended to by Anglo-American historians and sociologists before, say, the Korean War. Some historians seem to have been informed of it; many more, I think, were not; and only a very few saw reason to address its concerns. Pace Merton, it was not a major preoccupation of the history and sociology of science in that period to refute Marxist materialism nor to identify it as illegitimate 'externalism'. ${ }^{16}$

Secondly, the historical problem-area in which Marxist historiography developed through the 1940s and 1950s was overwhelmingly the interpretation 
of the Scientific Revolution or, more generally, the early modern origins of modern science. And when, from the 1950s, non-materialist historians became systematically engaged with Marxist views, it was the proper understanding of the origins of modern science that was seen to be at stake. Apart from Hessen's work on Newton, one can note Edgar Zilsel's essays on early modern science (c. 1942-45); Benjamin Farrington's book on Bacon (1951); Stephen Mason's papers on science and religion in the seventeenth century (1953); relevant sections of J. D. Bernal's The social function of science (1939) and Science in history (1954); and Joseph Needham's persistent contrast between European scientific take-off in the early modern period and Chinese failure (in essays dating from 1946). This focus had the effect of pitching materialist scholars against more traditional practitioners at just the point of greatest perceived cultural value and historiographic defensive strength. Moreover, materialist historiography was widely seen as an aggressive attempt to devalue science by displaying its banausic and practical origins. It was understood that to depict scientists as motivated by mundane and material concerns, to see the genesis of science more in craftwork than in philosophy, and to show that scientific concerns were animated more by the search for solutions to technological problems than by the disinterested quest for truth simply was denigration. The ancient ethical discourse which approved the liberal and condemned the mechanical arts in the formation of the gentleman, and which insisted on the philosopher's placement in a contemplative rather than an active posture, was unreflectively translated into debates over the circumstances in which modern science arose. Thus, what from present perspectives we tend to see as an academic discussion over the scope of sociological accounting appeared to many participants as a vitally important contest over the value of science and scientists in an age of unreason. ${ }^{17}$ It seems plausible that it was the Marxist work of the 1940s and 1950s, and aspects of the ideological context in which that work appeared, that was the proximate cause of the institutionalization of $\mathrm{e} / \mathrm{i}$ discourse and that drove many historians of scientific ideas to search out means of characterizing, opposing and containing the perceived threat.

Thirdly, to some extent these debates over the social relations of science were also informed by practical questions about the planning of science. This is especially clear in the British setting where science writers like J. G. Crowther and J. D. Bernal mobilized the history of science as a resource in arguing for greater political control of scientific research. Science was a body of truth and a powerful force in modern society. If science got to be the thing it was by social direction, then further social direction could do it no harm. The historiography of science thus appeared as a plank in the platform of the Labour as well as the Communist Party. ${ }^{18}$ And, of course, those politically opposed to the expansion of state power and the restriction of individual liberties also inspected the history of science for demonstrations of the 
impossibility of planning the production of truth. ${ }^{19}$ These and related considerations worked to charge up the e/i problematic and to make it seem both natural and consequential to a wide range of participants.

\section{I(b). THE SHORT AND UNHAPPY LIFE OF 'EXTREME EXTERNALISM'}

By the early 1950s both the history and the sociology of science were on the verge of recognizing the internal and the external as the fundamental resources out of which any theory of scientific change had to be constructed. From 1948 to 1953 the English Marxist engineer Sam Lilley used a popular science brief from UNESCO to publicize his scientistic externalism as a search for the universal causal laws of scientific development. The explanatory roles of the "internal order" of science and "external" social influences were prominently displayed. ${ }^{20}$ And in 1952 Rupert Hall contrasted a seriously flawed "sociological history of science" with historians' typical "internal view" and their enterprise of displaying "the logical development" of science. ${ }^{21}$ But perhaps the most significant landmark in the development of e/i discourse was the 1952 synthetic treatment of Science and the social order by Merton's student, the sociologist Bernard Barber. Here e/i "factors" - now prominently identified as such - were systematically dichotomized and mobilized in a general account of scientific change:

We may conveniently group the factors ... into two rough categories: the internal and the external factors. The internal factors include those changes which occurred within science and rational thought generally; the external include a variety of social factors. ${ }^{22}$

Barber closely followed Merton, however, in carefully constraining the scope of external factors in accounting for scientific change. While a traditional view of science as "entirely uncontaminated by the workings of social factors" was said to be no longer tenable, neither was the alleged vulgar economic reductionism of "the Marxian view": "The intellectual, the religious, and the political factors ... are no less influential always than is the economic factor." The external factors work together and mix together, "often together with influence from the internal condition of science itself". Science is "relatively autonomous", and its degree of autonomy depends upon the strength of its "conceptual schemes". Rigorous conceptual schemes "determine a certain line of development of their own; they do not then shape themselves simply in accord with some 'social need' ". ${ }^{23}$

Surprisingly, in view of the under-developed relations between history and sociology of science, Barber's treatment was instantly picked up and publicized by one of America's most eminent historians of medicine. Richard Shryock was possibly the first practitioner to elevate the vocabulary in 
question to title status: "The Interplay of Social and Internal Factors in the History of Modern Medicine." Shryock here not only cited Barber's (and Merton's) recent work, he also recognized and endorsed their judicious eclecticism about the scope of external accounting. "Extreme" views of the sufficiency of either the internal or the external were to be avoided: "the history of science can be understood only in terms of a constant interplay between internal logic and environment." ${ }^{24}$ Shryock had been well positioned historiographically to take full advantage of Barber's work. In the early 1930s he was working on a medical history survey whose subtitle offered "an interpretation of the social and scientific factors involved", ${ }^{25}$ towards which factors he favoured a soberly eclectic attitude:

My impression is that most Americans are disinclined to take either of these extreme positions. We do not think that the history of science is sullied by the inclusion of social backgrounds, but neither are we convinced that scientific ideas are simply products of economic determinism. [The history of science] can be understood only in terms of a constant interplay between internal logic and environment. ${ }^{26}$

For Shryock, as for many others in that setting, this eclecticism was pragmatically shaped and justified: it was, as Whitfield Bell remarked, "a practical way of getting sound historical work done", where an eclectic posture was a means of recognizing "sound history" when one saw it. ${ }^{27}$

By the early 1960s e/i discourse was securely institutionalized in the professional structure of the history of science. A 1957 anthology of articles from the Journal of the history of ideas juxtaposed essays by Zilsel and Alexandre Koyré in a form that made their divergent historiographies most visible. ${ }^{28}$ And while the 1957 Madison Critical problems conference was generally free of e/i vocabulary, it was then suggested that the next UNESCO/ IUHPS conference (at Oxford in 1961) ought systematically to discuss the relative role of "internal" and "external factors". ${ }^{29}$ In 1962 Kuhn's Structure of scientific revolutions implicitly offered a scheme by which external social influences might work to transform anomaly into conceptual crisis, or might operate early in the development of a new field and then be progressively excluded by processes of institutionalization. ${ }^{30}$ By the late 1960s the subtitle of a widely distributed pedagogically-orientated anthology of literature on the origins of modern science asked whether "Internal or External Factors" were responsible. ${ }^{31}$ In 1968 Kuhn's influential review of the state of the field identified strands of "internal" and "external" historiography as "virtually separate enterprises". 32

By the late 1950s and early 1960s, historians of science had generally concluded that, if they were required to comment, their proper posture was something between vigorously self-conscious internalism and temperate eclec- 
ticism. And here, as other scholars have observed, the role of Alexandre Koyré was crucial. Although some American historians of science were well aware of Koyre's pre-War work, his increasing North American presence from 1941 at a variety of U.S. universities (and later at the Princeton Institute), projected a coherent Platonist idealism onto the stage at just the point it was most likely to enjoy a friendly reception. Indeed, it has been suggested that a universalistic view of science as "essentially theory", was powerfully attractive in that environment for a number of reasons - intellectual, moral, disciplinary, and political..$^{33}$ In Cambridge Herbert Butterfield disseminated a broadly Koyréan picture of scientific change, as did Alistair Crombie at Oxford, Rupert Hall at Cambridge, Indiana and London, and Charles Gillispie at Princeton.

'Extreme externalism' was arguably born (made up?) in 1952, and by 1963, having endured a childhood of Dickensian abuse, it was being pronounced dead. In 1959 Charles Gillispie thought it "obvious" that "science", which is about nature, cannot be determined in its content by the social relations of scientists". "At most", Gillispie allowed, "it may be touched in style, in pace, and - within limits imposed by the logical interdependence of the sciences in order of development", though in so saying he was at one with Merton himself. ${ }^{34}$ Scholars such as Rupert Hall strongly identified the externalist project with Hessen's and Merton's historical claims and judged that Science, technology and society represented the end of a played-out Marxist tradition. "Crude" socio-economic interpretations have "perished without comment": "Clearly, externalist explanations of the history of science have lost their interest as well as their interpretative capacity." If Merton's 1938 text was the end of an old thing, Koyrés 1939 Études galiléennes was advertised as the beginning of a practice proper for a vigorous and autonomous academic history of science discipline. ${ }^{35}$

\section{I(c). EXTERNALISM IS DEAD, LONG LIVE ECLECTICISM}

Obituary notices for whatever positions and exemplars could be plausibly labelled as "externalism" were, therefore, not uncommon in the late 1950s and early 1960s. Far more interesting, however, were the means used to position proper historical and sociological practice between the poles erected by the $\mathrm{e} / \mathrm{i}$ problematic. Almost from the very origins of this problematic, historians and sociologists - especially, but not exclusively, in the United States - were largely of the view that "extremes" of either sort were illegitimate and ought to be avoided. Indeed, the proper procedure was deemed to be an eclectic selection of the respective "factors" and a judicious admixture of elements from both orientations towards scientific change. I have already noted a strong element of such eclecticism in Mertonian sociology, and it was also pervasive in the commentary of historians who, at least by attribution, 
belonged to one or other camp. Thus, the reputed externalist Sam Lilley echoed Mertonian sentiments when he wrote in 1948 and 1953 that "the development of science can be fully understood only if the internal and external types of influence are considered together and in their mutual interaction". ${ }^{36}$ And in 1952 the reputed internalist Rupert Hall claimed that the "two methods are complimentary, and [only] in extremes exclusive, for [the internal view] isolates the scientist from the world in which as a man he lives, [while] the latter places him at the mercy of his environment". ${ }^{37}$

By the 1960s the straits between Scylla and Charybdis were clogged with historiographic traffic. Again, as a methodological gesture, the same eclectic rhetoric seemed to be equally appealing to reputed internalists, to reputed externalists, and, of course, to the larger number of the non-committed and non-combatant. In 1961 Henry Guerlac - no notable externalist - expressed irritation at what he saw as the intolerant hegemony of the new idealists. "As a historian", Guerlac said, "I sincerely deplore" the fact that modest investigations of "social influences" were being dismissed with the sneer "interesting, 'mais un peu Marxiste" ". He wanted to "be free to use" Marxist orientations if they seemed warranted by the investigations at hand..$^{38}$

In 1966 one of Charles Rosenberg's earliest of a set of penetrating essays on science and American social thought traced a topography in which social influences might selectively act: "The more closely related to social problems, the more likely is a scientific field to be influenced by society's ever present demands." The historian's task was not to sort out matters of principle but to "explore specific instances and define the texture of specific relationships". There is "an aesthetic of complexity in history" that bridles at being required to endorse simplistic generalizations. ${ }^{39}$ An early Larry Laudan broadly agreed, parading a mature eclecticism uncharacteristic of his later philosophical incarnation. Laudan warned that "What we should avoid is dissipating our limited energies needlessly in pompous and protracted debates about the general nature of the history of science. Unless one is prepared to defend the highly dubious thesis that all scientific developments depend on the same sort of influences and pressures, then it is clearly foolish to argue that all (or even most) historical problems can be analyzed in the same way or in terms of the same categories of narration." Laudan applauded historians' "widespread common sense" in generally refusing to take up "an insoluble general debate about the kinds of forces affecting scientific change". ${ }^{40}$

And while R. M. Young's early essays on Darwinism became the rallyingpoint for some of the hardier social historians, we need to be reminded of the temperate eclecticism with which that work situated itself in historiographic space. Young deplored the polarization which set "internalists versus externalists" and judiciously commended the empirical study of "varied influences ... coming from inside and outside the 'scientific' community". ${ }^{11}$ When in 1968 
Young and Piyo Rattansi organized the King's College, Cambridge monthly seminar on "Science and History" which proved to have such lasting effects on the field, the "dichotomy", in Young's words, "between internal history of scientific ideas and external or social factors was regularly found to be at odds with" members' empirical historical investigations. Participants intermittently drew up lists of relevant "factors" but could not agree on any "overall approach". ${ }^{42}$ In 1969 Russell McCormmach introduced the new annual Historical studies in the physical sciences with a warm invitation to eclectic historiographic synthesis: "The vision of the history of science that relegates the historiographic traditions of internal and external history to mutually exclusive roles is sterile, obstructing the synthesis of the intellectual and social history of science that must come. I will be strongly sympathetic to studies that implicitly challenge the cogency of the currently held view of the internalistexternalist distinction." 43 It was a challenge most famously taken up in those pages by Paul Forman, whose controversial 1971 study of ideas of causality in Weimar physics nevertheless took care to circumscribe the domain of application of his "sociological" model: it "seems to work especially well in certain extreme cases". 44

Eclectic rhetoric proved durable. In 1974 the young(ish) Steven Shapin reckoned that a prosopographical approach might help to erode the barren "dichotomy between 'external' and 'internal' factors", and was speedily applauded for his eclecticism by Bernard Barber. ${ }^{45}$ At the same time, pursuing a Mertonian-style analysis of the "external audience" for eighteenth-century Scottish science, he was unsure whether he could securely establish social influences on scientific style or content. ${ }^{46}$ Indeed, through the 1970s few practitioners attempting the new social history of science expressed anything but uneasiness with the e/i problematic in which faute de mieux their work continued to be situated. Eclectic approaches "broadly bringing together the cognitive, internal, and external social factors" were increasingly popular, among some sociologists as well as historians. ${ }^{47}$ New empirical work was routinely commended for its "refusal to fall into any neat classification along 'internal' and 'external' lines". ${ }^{48}$ And historians sought to find some research site which enabled them either to bridge the perceived gap between internal and external or at least tactically to avoid confronting it. For many, that site was the 'institution' or the 'discipline', and the rhetoric of 'mediation' between internal and external flourished in the 1970s together with the fine achievements of institutional and disciplinary history. ${ }^{49}$ To critics, however, the vogue for history of scientific institutions was only made possible by setting aside that attention to scientific knowledge which might have allowed historians to address theories of scientific change. ${ }^{50}$

By the late 1980s historians were assimilating the new eclecticism to the 
playful jumble of post-modernist sensibilities. From this point(s) of view(s) e/i seemed an outmoded modernist brutalism. In 1988 Charles Rosenberg spoke no more than the truth when he noted that "In the past decade ... the great majority of historical practitioners have come to occupy increasingly nuanced and eclectic positions". ${ }^{51}$ Other historians now use the "passing' or 'transcendence' of the e/i disputes as an expository throat-clearer in much the same way that the matter-of-fact invocation of e/i in the 1960s and 1970s symbolically situated whatever came after. ${ }^{52}$ And even the smoothly sneering Robert $\mathbf{J}$. Richards provokes only nostalgia in a knock-about characterization of "externalism" and "social constructionism" as exclusive and "a priori" schemes. ${ }^{53}$ Bernard Barber, who was so instrumental in instigating the e/i problematic, now finds its early grip "incredible", approving the fact that sociologists (at least) gave it up by the early 1970s. ${ }^{54}$ No less an authority than Charles Gillispie has just pronounced the whole "distinction between internal and external approaches" to have been a "passing schizophrenia". 55

\section{SOME TROUBLES OF THE E/I DEBATES}

The temptation to agree with Professor Gillispie is overwhelming. I suggest, nonetheless, that we take one more look inside the madhouse before closing the door and tossing away the key. I do not think that our discipline ever conducted an adequately informed and systematic debate over what e/i was about, still less over the respective merits of each theory. And I think that much of what passed as debate was both diffuse and incoherent. (I am not here criticizing the contributions of individuals, many of whom may have had perfectly clear ideas of what $\mathrm{e} / \mathrm{i}$ was and how to assess the respective theories; rather, I am pointing to features of our communal discourse - the standard of rigour, clarity, focus and engagement that characterized our exchanges over e/i during almost half a century.) I want to make a number of observations about the e/i debate seriatim and without normal referencing to specific writers and writings. I hope that a stark and impersonal presentation will maximize the chances (a) that the issues concerned will be clearly visible, and (b) that my presentation of them will not (inevitably) be taken as a partisan and personal shot in the old conflict. 56

(i) Almost needless to say, the theories concerned were never well characterized in their own terms, and attributions of e/i by opponents and eclecticists were such as to make the other or the extremes indefensible. The characterization of the Merton thesis, by both proponents and opponents, has been a particularly dismal example of our abilities to read and represent to others a highly qualified and eclectic text. The debate never paused systematically to 
disentangle theories according some role to factor- $\mathrm{X}$ with those granting sufficient causation to that factor, nor to see whether theories of the latter sort were ever put on the historiographic agenda.

(ii) Treating externalism and internalism as theories of scientific change is the most coherent way to formulate them: scientific change proceeds (wholly/ mainly/partly) in response to intrinsic/extrinsic factors. Does such a thing as an 'immanent logic or rationality' of science exist? If so, does it exert a dynamic force in scientific change? If it does have a dynamic force, is this sufficient to account for scientific change? If insufficient, then in what ways must the posited 'immanent dynamic force' be supplemented so as to account for the actual course of historical change? Nevertheless, practitioners have intermittently invoked $\mathrm{e} / \mathrm{i}$ discourse not as theories of change but as directions of historical focus. Thus, externalism and internalism have been widely treated as those styles of research which happen to attend (wholly/mainly) to factors attracting the labels 'external' or 'internal'. Yet a practitioner who attends (generally or in a particular instance) to external factors may hold (in general or in that instance) an internalist theory of scientific change. And vice versa. Preference for treating one or another set of factors need have no formal bearing upon preference in theories of scientific change. Indeed, it is plausible that much speech about $\mathrm{e} / \mathrm{i}$ has simply acted as camouflage for practitioners deeply uninterested in any such theories. A style of research and writing does not amount to a theory about scientific change.

(iii) We have never systematically reflected upon our speech about 'factors' and their formal relationship to the opposed theories of scientific change. The results of this unreflectiveness become particularly manifest in much of the eclectic discourse which emerged by the 1970s. In many cases one was invited to endorse the sheer sensibleness of allowing some role to external-social and some to internal-cognitive factors. Eclectic sensibilities condemned the silly extremism of claiming that you could make a cake out of just flour or just sugar: of course (we were assured), you need some flour and some sugar. Yet, while the mixture of ingredients is indeed the right way to bake, it is not common-sensically evident that one can mix elements from qualitatively different theories of cultural change without dissolving the theories themselves. ${ }^{57}$ Hence, this sort of eclecticism, while it may well be the best-liked historical stance, cannot help resolve (or itself be a resolution of) a debate about the validity of the theories. A coherent and an important position might, however, claim that these theories are inappropriate to naturalistic inquiry. It might plausibly be argued that what we are accustomed to call 'science', and, accordingly, to theorize about, is a diverse set of cultural practices, which may not have common methods, conventions or concepts, or at least common features distinguishing them from 'non-science' or the common culture. If that 
position is accepted, then the claim ought to be that 'one cannot generalize about scientific change' not that 'the correct theory of scientific change is eclectically situated between two extremes'. ${ }^{58}$

(iv) It has not, I think, been systematically noted that there is a fundamental asymmetry in $\mathrm{e} / \mathrm{i}$ theories of scientific change. That asymmetry has both a formal and a practical aspect. Formally, something like 'pure internalism' can exist and be practised while 'pure externalism' cannot without historical contradiction. If the factors said to have influenced science came wholly from sources we call extrinsic to science, then, of course, historical actors would consider and act upon them as intrinsic, and the evidence of their behaviour would so reveal them to subsequent analysts. (And I assume the same with weaker force if the influencing factors are said to come only mainly from outside science.) Contrarily, since one may assume that all cultural practices are able to identify their intrinsic and extrinsic domains, their coherence and legitimacy will depend upon attending to the intrinsic and being wary of the extrinsic. ${ }^{59}$ Cultural action projects the intrinsic into actors' awareness and thence into the documentary record available to historians. It will, therefore, always be possible - without the slightest danger of contradiction - to do actor-orientated internalist history. Indeed, proponents of internalism have used the possibility of an internal history of science as a strong argument in its favour. Yet it is not the possibility of different forms of historical practice which has presumably been at issue, but their relative validity.

Practically, it is open to historians to notice and choose to interpret a range of behaviours engaged in by historical actors. For example, there is no necessity that historians studying Isaac Newton must attend to his natural philosophical practice and not to his role as university politician and supervisor of torture. It is a fact about our present academic arrangements that historians of science own the rights to talk about Newton rather than historians of politics. Historians of science project Newton into our cultural awareness and get to say 'what is important' about Newton. And it is a further fact that the history of science, as it has been, presently is, and likely will remain, is primarily interested in Newton as mathematician and natural philosopher. This practical interest thus conventionally circumscribes for us the domain of the intrinsic in Newton's life and work. Given some relationship between our conventional circumscription and what counted as proper to the practice of seventeenth-century natural philosophy, the role of the extrinsic must always appear as supplementary. If this is a correct analysis of the e/ $\mathrm{i}$ debates, then they were over before they started, and internalism was bound to be the winner.

(v) The e/i debates have been marked by massive incoherence and divergences of view over explanans and explanandum. Claims for, and attributions of, 
externalist explanation have ranged so widely as to overlap with claims for, and attributions of, its alleged historiographic opposite. Thus, in one form of accounting, external explanation is established by showing the influence of non-scientific forms of culture upon science, while in another the entire domain of the cultural (or cognitive) is taken as intrinsic and only the noncultural as extrinsic. ${ }^{60}$ Externalist accounting has, in various manifestations, identified its explanans as non-scientific culture (erroneous, irrational, metaphysical, aesthetic); scientific culture other than the variety allegedly influenced; yesterday's science (traditions or authority structures); social structures and processes within science (such as interested attachments to methods, schools and knowledge-claims); social and economic structures outside of science (considered as non-cognitive, and actively conceived as interests or passively as reflections of extrinsic realities). Similarly, externalist explananda have been characterized as encompassing scientific culture as a whole, including its methodological and metaphysical elements, its dynamics or foci of interest. Debates have been so poorly focused that the general form of 'key' achievements in externalism have been taken as identifying the 'key' tenets of internalism.

Furthermore, it has largely escaped notice that if the explanandum of externalist claims was taken as the dynamics of different scientific research areas - as many critics and proponents said it was - then the arrangements of present-day science offer strong evidence in its favour. However vigorously modern scientists may strive to bend politically endorsed directives to their own ends, it is unlikely that anything like a Human Genome Initiative would have autonomously emerged from an internal agenda of molecular biology. The identification of 'disinterested curiosity' as an individual motive is not incompatible with the claim that curiosity tends to flow towards the heaviest concentrations of cash. 'Actor-orientated' analysis is laudable but it is also insufficient, since other actors may affect the behaviour of those in whom we happen to be interested.

(vi) The e/i debates have never systematically interrogated, defined or defended the modes of causative action presupposed by each theory of scientific change. Insofar as externalism has been construed as the influence of the non-cognitive upon scientific cognition and its intellectual products, it shares with materialist analysis generally the Cartesian problem of accounting for how the intellectual can be shaped by that which is not itself intellectual in form. And insofar as internalism has claimed that ideas can cause the development of further ideas, it shares with idealism the apparent nonsense of attributing agency to items which the testimony of modern natural science itself suggests are the products of human agency. The 'self-direction' of ideas (if literally meant) appears scientifically absurd, and (if meant only as a 
manner of speaking) may overlap with forms of externalism. More fundamentally, the division of the e/i explanatory world into the cognitive (science) and the non-cognitive (society) has never been systematically defended. Nor can one imagine a plausible reflective defence against the observation that both 'society' and 'science' (naturalistically construed) are systems of cognizing agents, collectively arrayed, doing things together on the basis of what they know.

(vii) The point of action of different theories of scientific change has never been systematically identified. In much externalist practice (and critical characterizations thereof) the influence of extrinsic factors is taken as bearing upon individuals' motivations (with motivations taken as inner mental states). When individuals do not provide empirical evidence of these influences, it has not been clear whether the conclusion ought to be negative or whether the analyst is then to adduce such problematic categories as 'unconscious motivations'. ${ }^{61}$ Similarly, inference from actors' statements about their motivation to their motivation (considered as a psychic state) has rarely been regarded as problematic among historians of science, even though it is understood as intensely problematic in everyday life and in certain strands of academic philosophy. ${ }^{62}$ Other externalist genres have largely eschewed the motivational point of action in favour of identifying social structural biases. ${ }^{63}$ The internalist point of action is equally unclear: in the pure form, in which ideas cause other ideas, any contact with individual-psychological or collective-sociological structures is moot, while, in less idealist forms, internalism may specify what motives are proper for a genuine scientist to possess and thus generates tension with naturalistic inquiry.

A related move assesses theories of scientific change according to whether or not alleged motives were successfully realized in scientific action. Thus, it has been a popular argument against 'externalism' that utilitarian motives cannot have systematically operated upon proper scientific activity in the early modern period because the allegedly hoped-for outcomes were not obtained. But this is positivism pure and simple: it assumes an efficacious scientific method which will illuminate whatever target it is directed to. And while cruder forms of externalism undeniably include positivist elements, so do many varieties of internalism.

(viii) A pervasive feature of the e/i debates has been an equation between the 'external' and the 'social'. From the emergence of the problematic through the 1980 s most commentators have used 'the social' and 'the external' as synonyms. The usage is as commonplace as it is unjustifiable. There is as much 'society' within the scientific community, and scientific workplaces, as there is outside them. Scientific work is no less collective and coordinated than is everyday social life, and arguably it is much more so. For at least twenty years the 
major, most solid, and least contentious of the contributions of the sociology of scientific knowledge has been to provide resources for eroding such a distinction. And yet, in certain quarters of our disciplines, it persists.

If 'society' is defined as that which goes on outside of 'science', then the relationship between the one and the other will indeed be inscribed in the language of 'influence' and 'mediations'. The task of the externalist (thus considered) will be to display the chain of influences and mediations leading from outside to inside. And indeed spatial metaphors, the language of cause, contamination, core and shell, will provide the resources for construing successful and unsuccessful demonstrations. Much of the empirical sociological work of the 1970s accepted that problematic and sought to show 'social influences' in technical and esoteric scientific claims and judgements. Such work now seems sociologically far too modest. ${ }^{64}$

In a philosophical idiom e/ $\mathrm{i}$ appeared to many as a contest between the role of 'reasons' and 'causes' in the history and sociology of science. The former were commonly conceived as the legitimate springs of action proffered by deliberative individuals; the latter as the brute forces of collectivity bearing in upon and coercing the otherwise rational actor. Talk of 'social influences' merged imperceptibly into the evaluative language of constraint and coercion, while the domain of the autonomous individual was common-sensically identified with freedom and rational choice. Again, while such depictions arguably have deep roots in cultural history and everyday speech, much sociology of scientific knowledge was in fact predicated upon highly calculative models of the individual-in-society, and ethnomethodological strands stressed individuals' 'artfulness' to the point where the very existence of an 'influencing' social order became moot.

The equation between the external and the social therefore is best treated in the idiom of cultural history or functional sociology as an evaluation. It is a pervasive way we have in our culture of stipulating the posture and circumstances in which valuable culture ought to be made. Many features of the history of these debates, including explicit statements by participants, lend support to the notion that e/i was deeply shaped by concerns to say 'good' or 'bad' about science. In important respects, this evaluative-descriptive discourse traces back to the Greek preference for contemplation (theoria) over praxis, and it surfaced in just that form in the 1930s and 1940s debates over whether modern science emerged in the isolated scholar's study or the craftsman's collective workshop. Both secular-philosophical and religious sensibilities stipulate solitude as the proper site for the appearance of truth. And empiricist-inductivist models of scientific discovery are powerfully supported by individualistic conceptions of social order. ${ }^{65}$ In the 1980s, philosophers' role in the e/i debates predominantly took the form of a defence of reason against 'the social', and, even though important philosophical re- 
sources were available for understanding scientific activity as a collective phenomenon, ${ }^{66}$ some of the most polemical interventions by philosophers of science simply assumed the validity of contrasting 'the rational' and 'the social'.

(ix) Trouble (iv) identified a deep asymmetry in the e/i debates. This was predicated upon historical inquiry into actors' behaviour with respect to their senses of the intrinsic and the extrinsic. Yet it is evident that most participants in the e/i debates have been remarkably uninterested in this historical sensibility. Instead of discerning the internal and the external in historical actors' terms, analysts have been overwhelmingly content to speak of scientific boundaries as if they were those obtaining or normative in present-day science. While such a procedure is understandable within an evaluative and teleological historical practice, it is not clear what role it plays within an academic community mobilized around the naturalistic goal of telling history wie es eigentlich gewesen.

More generally, historicist orientations (otherwise highly popular among cultural historians and historians of science) potentially wreak havoc on the boundary-talk inscribed within the e/i debates. Putting 'the social' to one side, what is the justification for interpreting - say - seventeenth-century science as a single bounded entity within which all elements are self-evidently intrinsic? Historicist sensibilities encourage us to recognize consequential discursive, methodological, practical, epistemological, and social boundaries between, for example, seventeenth-century mathematics and philosophy. And with what entitlement do we identify even such an entity as seventeenth-century English natural philosophy as one bounded domain? Again, historicist orientations identify disputed natural philosophical practices, each with its different prescription of the intrinsic-legitimate and the extrinsic-illegitimate. What do 'the' internal and 'the' external look like when the field is contested - when, indeed, there is disagreement over what and where the field is? What, if any, common bounded discourse is available to the contestants? It is one of the more surprising results of a survey of the e/i debates since the 1950s that historians of science have not been greatly interested in treating cultural boundaries in a genuinely historical manner. Indeed, pronouncements of the death or transfiguration of $\mathrm{e} / \mathrm{i}$ issues have preceded any systematic exploration of the complex situated practices historical actors have used to construct their internal and their external domains.

\section{RESOURCES FOR REVIVING THE INVESTIGATION OF SCIENTIFIC BOUNDARIES}

Historians' view of the new sociology of scientific knowledge which emerged in the 1970s has customarily been refracted through the lens of the e/i debate. 
Given the common-sensical equation between 'the social' and 'the external', what else could sociological accounts of scientific knowledge be but a new twist on the old externalism? In fact, far from falling in with the terms of the traditional e/i debate, leading sociologists of scientific knowledge repeatedly expressed scepticism about the interest and legitimacy of that problematic. While arguing for the irreducibly social character of scientific activity, it was never any part of these sociologists' case that considerations pertaining to the wider society (what are conventionally called 'external factors') must be part of any particular sociological account. Whether or not an externalist account was indicated was regarded as a wholly contingent matter. Indeed, sociologists noted, it is entirely plausible that the professionalized and insulated status of much modern science means that considerations relating to individuals' partypolitical affiliations, class background, religion, and the like are rarely relevant to explanations of theory-choice or fact-judgement. ${ }^{67}$

The most systematic defence of a genuinely historical engagement with the problem of scientific boundaries was produced as long ago as 1974 by the sociologist Barry Barnes. ${ }^{68}$ Since that argument seems to have been littlenoticed by historians of science, the main strands of Barnes's case, and some considerations that follow from it, can usefully be summarized here. Firstly, it is suggested that analysts be wary of importing present-day boundaries and the evaluations they express into the study of past science. We should seek to discern how past actors cut up the cultural terrain. To impose our categories on them is to block both historical understanding and the capacity for sociological explanation. Historians are supposed to want to know how actors themselves perceived their circumstances, and sociologists are supposed (at least occasionally) to want to explain actors' behaviour. Explanation may depend upon understanding. Actors who cut up the cultural domain into the legitimate and the illegitimate can be expected to behave differently according to their sense of where cultural resources are located. Of course, even a preliminary engagement with actors' categories informs us that the notions of 'science' and the 'non-scientific' do not capture the discourse of many past practitioners in whose work we may have an interest. There need not be anything especially alarming about this. A project aimed at interpreting past culture can live as happily with the categories of "natural philosophy" or "ye mathematickes" as with "science", and an inquiry aimed at interpreting or explaining historical change can - if practitioners are so minded - treat the history of "science" as the history of antecedent cultures, however these were labelled and constituted.

Secondly, a naturalistic actor-orientated inquiry into scientific boundaries can take a thoroughly matter-of-fact view about whether or not the history of science displays evidence of external influence. Indeed, if science is analysed as a form of culture like any other, then it is wholly to be expected that it feeds 
upon itself and that it does not respond simply or directly to material, social or cultural factors beyond its domain. If and as it takes such factors into itself, it is through a process of turning them into relevant cultural items and processing them according to standards obtaining in its domain. Accordingly, the continuity and coherence so beloved of internalist historians amounts (in sociologists' vocabulary) to the display of science as a typical form of culture. Sociologists have as much reason as historians of ideas to identify and interpret evidence of cultural coherence and continuity. Sociologists may point to the institutional means by which culture is transmitted and maintained while many historians may continue to prefer to speak of inherent logic and self-regulation. ${ }^{69}$ But historians ought at least to know that cultural continuity can be otherwise accounted for.

Thirdly, in interesting cases the identification of cultural elements as internal or external is fraught with difficulty since the relevant actors are in deep disagreement. Thus, for many nineteenth-century geologists and biologists, to behave in a legitimate scientific way was to be a uniformitarian, while others regarded uniformitarianism as an empirical claim to be verified or falsified by evidence, and still others saw commitment to it as doctrinaire and illegitimate. Actor-orientated history - otherwise so valuable - cannot solve such a problem without making some actors' voices inaudible. Here we have to observe the processes by which community judgement coalesces around one or other boundary-frame, including the deployment of more stable cultural elements whose own solution of the external/internal problem is a shared resource.

For all the straightforward historical common-sense of Barnes's treatment, it seems to have had little impact on the e/i debate as it continued through the 1970 s and early 1980s. What Barnes was proposing was far from the eclectic dismissal of the e/i problematic that was gaining popularity among historians. Rather he offered a programme for empirical research into the constitution and consequences of scientific boundaries. In a review article which has been otherwise well-noticed I tried to publicize a similar argument myself, only to find that programme widely labelled as 'externalism'. ${ }^{70}$ In my own view, a historicist perspective on scientific boundaries was a good vehicle for moving forward both the sociology of scientific knowledge and a naturalisticallyconceived history of scientific culture. My 1985 book with Simon Schaffer represented, in part, just such a sensibility. We wanted to trace the contours of a cultural practice in which parties disagreed about what a proper natural philosophical practice was and where its internal and external boundaries ought to be located. Specifically, Robert Boyle reckoned that a well-founded natural philosophy ought to put to one side questions of real causes as well as matters of church and state. The condition for the new philosophy being able to contribute to moral and civil order was its visible exclusion of both the 
contentious and the interested from its practice. Thomas Hobbes, however, claimed that no practice so constituted was properly philosophical, and, since philosophy alone could produce secure knowledge, Boylean experimentalism was both illegitimate and dangerous. We concluded that exercise by an invitation to revive a reformulated $\mathrm{e} / \mathrm{i}$ debate, and the intervening years have done little to change these sentiments:

Insofar as we have displayed the political status of solutions to problems of knowledge, we have not referred to politics as something that happens solely outside of science and which can, so to speak, press in upon it. The experimental community vigorously developed and deployed such boundary-speech, and we have sought to situate this speech historically.... What we cannot do if we wish to be serious about the historical nature of our inquiry is to use such actors' speech unthinkingly as an explanatory resource. The language that transports politics outside of science is precisely what we need to understand and explain. We find ourselves standing against much current sentiment in the history of science that holds that we should have less talk of the "insides" and "outsides" of science, that we have transcended such outmoded categories. Far from it; we have not yet begun to understand the issues involved. ${ }^{71}$

\section{IV(a). RESOLUTIONS OR DISSOLUTIONS?}

Finally, I want briefly to discuss two currently popular science studies frameworks, both of which have proved powerful solvents of the traditional assumptions and categories of the e/i debates and both of which, I suggest, need to be carefully scrutinized and qualified if they are to be put to constructive use in the history and sociology of science. The first has already been introduced. I take historicism in a loose sense, as the programme dedicated to analysing historical action in historical actors' terms. When applied to the study of scientific culture, historicism is a potent check on the brand of presentism which has blocked properly historical investigations of scientific boundaries. Historicism, for example, argues against the legitimacy of treating religion straightforwardly as a factor external to seventeenthcentury science if historical actors acted as if religious considerations properly belonged to science. And historicism encourages curiosity about how the domain of "natural philosophy" was constituted and demarcated from, say, civil philosophy and natural history.

Yet historicism is accompanied by some methodological baggage that warrants close inspection. The risk is that the admirable historical goal of understanding actors' categories can wind up dissolving the subject-matter of history of science into atomizing particularism. Unless we can find some 
argument to the contrary, the category we are enjoined to understand will progressively dissolve from 'science' to 'seventeenth-century natural philosophy' to 'Newton's version' of that category, and, by natural extension, to 'Newton's version of natural philosophy as detailed to Richard Bentley in 1692'. Here the individualistic reflexes that characterize much history may be usefully disciplined by the sociologist's collectivism. We should view actors' categories like cultural boundaries as institutions. That is to say, we can understand them as a set of constructed and maintained marks in cultural space which allow collectivities effectively to tell members where they are, where they may and may not go, how permissibly to behave in this place. The historian can identify these institutions empirically through their public use as resources for coordinating activity: they are means used by actors to say 'right' and 'wrong', 'legitimate' and 'illegitimate'. And, as these resources are so identified, they may figure as well in explanatory as interpretative exercises. Individuals may indeed propose new ways of cutting up the culture and new distributions of value, yet unless and until these are institutionalized they have no bearing upon interpretation and explanation of collective action.

The second science studies framework emerges from the work of Bruno Latour and his Parisian colleagues, and, although it is probably just entering the awareness of most historians of science, Latour's work merits historians' serious consideration, for he proposes the most fundamental dissolution of the categories in which we have spoken of the external and the internal, the social and the scientific. ${ }^{72}$ Latour rightly points out that what counts as 'science' and what as 'society' are the results of trials of strength. Thus, to speak of 'social influences on science' is, in the current sociological commonplace, to use as a resource what ought to be a topic of inquiry. How are the 'social' and the 'scientific' constituted? Latour was not the only writer in the 1970s and 1980s pointing out that there was as much 'society' inside of 'science' as outside, though his work was a powerful stimulus to that realization. More original is Latour's relational sensibility to the objects of historical and sociological inquiry. He argues that we do not encounter modern social action without encountering also the technical and scientific, and, symmetrically, that we never confront science without confronting social action and politics. The objects which students of science seek to analyse are never 'pure science' and "pure society': they are "actor-networks" in which the humans are connected to other humans, things to other things, and things to humans. Where is the external social which is said to influence science? And what is the internal domain which is said to develop according to its immanent logic? The traditional $\mathrm{e} / \mathrm{i}$ debate is said to be vacuous because it manipulated the wrong ontology.

As a metaphysics for science studies, Latour's actor-network theory is both potent and attractive. If historians and sociologists of science feel they would 
like a metaphysics, Latour's has some appealing features. It rightly dissolves any discourse which depends upon 'society' and 'science' having distinct real essences. Yet it remains unclear what historians and sociologists are supposed to be able to do with the new ontology. Many advanced practitioners now agonize about whether or not Latour means them to 'take seriously' as an ontology a world in which human beings and scallops are both 'actants' and in which the selective attribution of speech and agency to the former is merely an impermissible appropriation of the findings of the very sciences we seek to interpret. Latour himself has suggested that we need a new "amodernist" project which transcends not only the 'society-science' dualism that figured in the e/i debates but a whole range of fundamental modernist dualities including 'subject-object' and 'human-non-human'. ${ }^{73}$ Critical appreciations of Latourian ontology, epistemology and method have recently appeared and I need not summarize them here. ${ }^{74}$ Nevertheless, I want to point out a particular problem in adapting Latour's project to more traditional historical and sociological inquiries, not least because an eclectic attitude towards this work runs the risk of missing its radical character.

According to Latour, historians and sociologists should no longer talk of 'science' and 'society' but only 'stronger and weaker associations' of heterogeneous elements. ${ }^{75} \mathrm{We}$ must, he says, abandon e/i discourse because crucial terms in that discourse are analytically invalid: 'science' and 'society' do not exist as pure forms, and certainly not within their common-sensical boundaries. Here there is some superficial accord between the Latourian and the historicist project. For past actors' ways of dividing up their worlds may be (indeed typically are) at odds with our common-sensical classifications and our preferred ontology. Returning to the toy-example, many seventeenth-century English natural philosophers cut up their culture so as to include important elements of religion within the practice of natural philosophy. The institutional boundaries used to coordinate activity were therefore different from those we now entertain. The culture in which many seventeenth-century practitioners operated included, as real existents, many entities which (if the dogmatism may be forgiven) do not exist: miracles, the immortal and immaterial soul, heaven, hell, and the weapon salve. Insofar as these entities were institutionalized resources for effecting coordinated action, historians want to understand them and how they were conceived to work. That does not mean that we have to believe in their physical existence and act accordingly; it does mean that we have to seek to understand how historical actors believed in them and how they acted accordingly. It means that we momentarily try to suspend what we know about the world in the cause of understanding what they knew. Of course, the distinctions between 'science' and 'society', 'the social' and 'the intellectual', are analytically false. Of course, such categories do not have distinct essences. That is because they, and the contingent 
boundaries between them, are made out of the same stuff - culture - and sustained by the varying cultural practices of historical actors. And it is with the production and manipulation of culture that the historian is concerned. So far as the historicist practitioner is concerned, Latour's metaphysics appears as a useful way, along with others, to clear the mind of some current prejudices before setting out to study science.

\section{IV(b). SCIENTIFIC BOUNDARIES AND THE LIMITS OF ACADEMIC PURITY}

The generation that developed e/i discourse reckoned that the academic study of science could, and ought to, 'make a difference' in the arrangements between science and society subsisting outside the academy. Many scholars from the 1930s through the 1950s were committed not only to showing how their disciplines and sub-disciplines might illuminate the nature of science and scientific change, but also to defending and justifying some current arrangements of science in society. For Merton and his followers this was liberal society and a conception of the scientific economy as a marketplace; for idealist historians it was perhaps the philosopher-kingdom or whatever social arrangements sustained and valued the role of abstracted thinkers; for socialists it was a society where the needs of all framed scientific agendas and where an accountable science progressed through its responsiveness to the wants of an egalitarian society. These commitments motivated much academic study of science - internalist and externalist, good, bad, and indifferent. And these same commitments, it is easy to say, were at the root of the 'mistakes' made by the founding fathers in originating and perpetuating externalism and internalism as the organizing principles of the history and sociology of science. These principles were sustained by those commitments.

We are different. The generation which began coming into the history and sociology of science from the mid-1970s has been relatively free of any such commitments and it has increasingly celebrated that freedom by insisting upon the autonomy and purity of disciplinary discourse. ${ }^{76}$ The sons and daughters of luxury have tended to be more interested in performing rites of disciplinary purification than in changing the world, while the most luxurious delusion of all has been that disciplinary purification is itself an effective means of changing the world. We ought to be a bit sceptical about academic exercises that seek to achieve purity through the use of exclusionary language. And we ought to find it more culpable than curious that any enterprise using highly exclusionary language should represent itself as a force for social change. So far as the history and sociology of science are concerned, luxury has significantly expressed itself in rejecting the improprieties and constraints framed by $\mathrm{e} / \mathrm{i}$ discourse. That discourse has more and more come to appear as some sort of impurity, binding the academic study of science to the scientific community,

\section{Provided by the NASA Astrophysics Data System}


to other disciplines whose concerns with science were less disinterested, to politics, and to the common culture. In order to achieve a properly historical, or authentically sociological, engagement with science, it is now said, we have to reject these ways of going on, to purge our discourse of the elements of common speech. The power of understanding, as well as the integrity of our disciplines, is reckoned to proceed from the purity of our speech. Some even say that if we cannot find a virtuous speech that allows us reliably to refer to real entities called 'science' or 'society', science studies ought to be reconstituted as an immaculately reflexive discourse about 'self' or its own methods for constituting its subjects and objects. Then all our problems would be solved: a practice that did not seek to refer to 'science' and 'society' would be pure indeed.

While the Latourian project trades in an ontology which - so far as we know - no historical actors have ever recognized, the historicist project seeks to jettison present categories in favour of those of the past. It is hard to imagine any posture other than a broad historicism compatible with what now counts as 'proper history'. Yet, such is the current enthusiasm for historicism that there is some danger of naiveté about the extent to which, and the conditions in which, that sensibility can be realized. As with all inquiry aimed at communicating about 'people like them' to 'people like us', historicism contains an ineradicable realist bias towards 'us'. However charitably we interpret a culture inhabited by a providential God, it is neither obligatory nor (in most quarters) permissible to write providentialist history. ${ }^{77}$ We say that Boyle believed that God guaranteed his discoveries not that God did so. If in seeking historicist understanding we did no translation, if we did not avail ourselves of any modern knowledge, and if our accounts used the actual concepts, categories, and methods recognized among seventeenth-century natural philosophers, we might well achieve historicist purity, but at a cost: we would certainly fail to communicate our understandings to our own academic colleagues and to constituencies outside the academy. ${ }^{78}$ (A consistently pure position can, of course, be attained: we can keep silence or we can produce persuasive forgeries of past culture.)

Moreover, while we may decide that the metaphysically correct view of the world is one containing 'stronger and weaker heterogeneous associations', we find ourselves (still) seeking to interpret and explain modern worlds populated by actors, many of whom, and on many occasions, manipulate entities called 'science' and 'society'. Indeed, these locutions capture something tremendously important about the modern world, something we might want to call analytically wrong but culturally consequential. And here the mismatch between the Latourian project and the historicist project becomes evident, just because we happen to share more culture with the actors whose behaviour we propose to interpret. In the world in which we now live scientists and other 
social actors use 'science', 'society', and the boundaries between them to coordinate their activities and to distribute value. In that precise sense, 'science', 'society', and the boundary-discourse occasionally used in actors' practice, have got as much ontological right, and as much right to be used as analysts' 'categories' as 'stronger and weaker heterogeneous associations'. It is both legitimate and possible to construct a metaphysics compatible with historical and sociological inquiry. But it is a category mistake to conflate a metaphysical project with those concerned to explicate concrete cultural practices.

There is no doubt of the many benefits we now enjoy through the rejection of traditional e/i discourse. Our current understandings of science are arguably much better just because the older conventions and classifications have been so severely criticized. That process is irreversible, and, I am sure, rightly so. Nevertheless, I stress that there may be prices to pay if we continue on the present course. One price is that as the discourse of our academic disciplines becomes more pure so it becomes more irrelevant to anything outside the disciplinary boundaries we have constructed. The price of purity is privacy. As we reject distinctions between 'science' and 'society', 'internal' and 'external', 'human being' and 'scallop', so we find ourselves puzzled what to say to scientists, politicians, and laypeople whose understandings of the world may trade in these categories and whose practical activities in the world manipulate them. To the extent that we reject their categories we reject the possibility of charitably understanding them as historical actors, and, of course, we reject the possibility that our speech can make a difference to them as members of our own society. Why should we be surprised if that rejection of present-day categories which allows us to speak with the past creates problems for our speech with the present? If we are committed to communicating with presentday scientists and laypeople, then there is no reason to pander. There is, however, every reason to recognize how powerfully entrenched in everyday life are institutionalized understandings and modes of speech about science. If new science studies perspectives come to have an influence, the meanings of the terms 'science' and 'society' will change to reflect new understandings. There is no need to invent a new vocabulary for this. But the price of communication to institutions as powerful as science is hard work and an awareness that it may take a long time to succeed: we succeed only in fooling ourselves if we think otherwise.

Assuming that some historians and sociologists do want to have conversations in the common culture, the predicament we are in admits of no formulaic resolution. Our situation is impure, inconsistent and compromised insofar as we wish to talk about the past to our disciplinary colleagues. It is even more massively impure if we wish to talk about the past in the common culture. For these and other reasons, it is probably not worth making a fetish 
over the use of words. The abolition of such words as 'external' and 'internal', 'science' and 'society', in itself solves nothing. For all the traditional malpractice associated with their usages, they are only words, and, like other words, we can give them different meanings in different contexts of use. We can use them to express scepticism about their legitimacy, in just the same way that, for example, the dualist language of 'mind' and 'body' has been deployed by those advocating a materialist theory of mind. We can even alternate between the senses of usages, moving back and forwards between actors' and analysts' points of view and the locutions appropriate to each. And, despite some historicist pipe-dreams, this is what reputable historical practice inevitably does. Accordingly, once our predicament is confronted, the strength of pragmatic ways of coping with it becomes evident. Communication imposes compromise. A fetishism of words is vacuous. The history of e/i discourse is one of insufficient scepticism about the sense and application of those locutions. Our present task is not acquitted by eliminating such categories from our interpretative vocabulary, but by being sceptical over their usage, and by pressing that scepticism as far as it will go - consistent with our commitments to communication.

\section{ACKNOWLEDGEMENTS}

For comments on an earlier version of this paper I thank Harry Collins, Gary Hardcastle, Philip Kitcher, Bruno Latour, Michael Lynch, Andrew Pickering, Charles Rosenberg, Simon Schaffer, and Andrew Wayne. It was originally presented at a session of the History of Science Society annual conference at Madison, Wisconsin in November 1991, and I thank the Society for its assistance. Research was supported by a University of California President's Research Fellowship in the Humanities and by a Fellowship from the National Science Foundation (DIR 90-23396).

\section{REFERENCES}

1. Apart from the reviews referenced below, I want also to acknowledge: R. MacLeod, "Changing perspectives in the social history of science", in I. Spiegel-Rösing and D. de S. Price (eds), Science, technology and society: A cross-disciplinary perspective (London, 1977), 149-95; N. Reingold, "History of science today, 1. Uniformity as hidden diversity: History of science in the United States, 1920-1940", The British journal for the history of science, xix (1986), 243-62; A. Thackray, "The pre-history of an academic discipline: The study of the history of science in the United States, 1891-1941", Minerva, xviii (1980), 448-73; and H. M. Collins, "The sociology of scientific knowledge: Studies of contemporary science", Annual review of sociology, ix (1983), 265-85. As this piece was being written, I became increasingly aware of the extent to which e/i talk appeared predominantly as an Anglo-American concern. Dutch, French and German commentators on earlier drafts pointed out some Continental resonances of these debates (e.g., the 
'finalization thesis'), while generally confirming that historical and sociological studies of science in their countries were, for a variety of reasons, not nearly so obsessed with $\mathrm{e} / \mathrm{i}$ as the United States and Britain. A recent review of French traditions of science studies, for example, has scarcely any reason even to mention e/i, speculating that the early French "defeat of empiricism" made any such discourse about science seem quaintly AngloSaxon: G. Bowker and B. Latour, "A booming discipline short of discipline: (Social) studies of science in France", Social studies of science, xvii (1987), 715-48, p. 741.

2. See, e.g., M. Douglas, Purity and danger: An analysis of concepts of pollution and taboo (London, 1966).

3. See, among very many examples, Emile Durkheim's discussion of claims for "wholly internal" methodological rules in each science: The division of labor in society (New York, 1964; orig. publ. 1893), 367-8; also H. Kuklick, "Boundary maintenance in American sociology", Journal of the history of the behavioral sciences, xvi (1980), 201-19.

4. See, for example, M. Oakeshott, Experience and its modes (Cambridge, 1933); A. MacIntyre, After virtue: A study in moral theory (Notre Dame, Ind., 1981), esp. ch. 15.

5. E.g., M. Foucault, "The order of discourse", in R. Young (ed.), Untying the text: A poststructuralist reader (London, 1981), 48-78, esp. pp. 49, 55-56, 61-62 (quotation from p. 56); $c f$. P. Bourdieu, "The specificity of the scientific field and the social conditions for the progress of reason", Social science information, xiv (1975), 19-47, esp. p. 22.

6. K. Mannheim, Ideology and utopia: An introduction to the sociology of knowledge (London, 1936; orig. publ. 1929-31), ch. 5, quoting pp. 239-40, 261 (cf. 150).

7. In early modern practice the Port Royal logicians referred to the evidence of things as "internal" and that of testimony as "external": I. Hacking, The emergence of probability (Cambridge, 1975), 33, 37, 79. And in modern philosophy of science Rudolf Carnap, for example, discriminated between the "internal" and the "external" as a way of delimiting sensical and non-sensical, answerable and non-answerable questions, within any given linguistic framework, including the natural sciences. But Carnap never associated the "external" with extrinsic sociological considerations, and his usage appears entirely independent of the e/i debates in history and sociology of science: Carnap, Meaning and necessity: A study in semantics and modal logic (Chicago, 1958; orig. publ. 1947), 206-7.

8. I. Lakatos, "History of science and its rational reconstructions", in R. C. Buck and R. S. Cohen (eds), PSA 1970 (Boston Studies in the Philosophy of Science, viii; Dordrecht, 1970), 91-108. Few historians, however, noted just how much of what they routinely accounted 'external' was encompassed within Lakatos's 'internal history'. One of the more systematic recent philosophical defences of internalism and scientific "rationality" against (a badly misrepresented version of) "cognitive sociology" is L. Laudan, Progress and its problems: Toward a theory of scientific growth (Berkeley, 1977), ch. 7.

9. S. Shapin, "Understanding the Merton thesis", Isis, lxxix (1988), 594-605, and the subtle but unfairly neglected M. D. King, "Reason, tradition, and the progressiveness of science", History and theory, x (1971), 3-32, esp. pp. 9-17. For an intriguing and informative firsthand account of circumstances bearing upon the emergence and early reception of Merton's Thesis, see I. B. Cohen, "Introduction: The impact of the Merton Thesis", in idem (ed.), Puritanism and the rise of modern science: The Merton Thesis (New Brunswick, N.J., 1990), 1-111.

10. R. K. Merton, Science, technology and society in seventeenth-century England, new edn (New York, 1970; orig. publ. 1938), e.g., pp. xviii, xxix, 48, 50, 75, 136, 198-200, 238; idem, "Puritanism, pietism and science", in idem, Social theory and social structure, rev. edn (New York, 1957), 574-606, p. 579. It was not obligatory that demonstrations like Merton's should employ the vocabulary of internal and external; see roughly contemporary historical work by Dorothy Stimson which is free of such locutions: "Puritanism and

\section{Provided by the NASA Astrophysics Data System}


the new philosophy in 17th century England", Bulletin of the Institute of the History of Medicine, iii (1935), 321-34 (cf. Cohen, op. cit. (ref. 9), 83, n. 96).

11. P. A. Sorokin, Social \& cultural dynamics: A study of change in major systems of art, truth, ethics, law and social relationships, 1 vol. abridged edn (Boston, 1957; orig. publ. in 4 vols, 1937), 18-19 (also 64, 630ff). Sorokin repeatedly urged the young Merton (with partial success) to give up causal speech of "stimulant-stimulated" in favour of Vilfredo Pareto's anti-causal scheme: R. K. Merton, "The Sorokin-Merton correspondence on 'Puritanism, Pietism and Science,' 1933-34", Science in context, iii (1989), 291-8. Talcott Parsons's contemporary theoretical work confirms the Harvard academic significance of Sorokin's thinking about 'immanent logics', and offers a potted philosophy of science broadly compatible with Merton's sensibilities: T. Parsons, The structure of social action, 2nd edn (Glencoe, Ill., 1949; orig. publ. 1937), 5, 11, 21-27.

12. My impression is that most standard texts did not even allude to the relative motive power of 'external' and 'internal' factors. Examples of glancing engagement with these issues include: H. T. Pledge, Science since 1500: A short history of mathematics, physics, chemistry, biology (London, 1939), 14-15, 322-4; W. C. D. Dampier-Whetham, A history of science and its relations with philosophy \& religion (Cambridge, 1929), ch. 3; A. C. Crombie, Augustine to Galileo: The history of science A.D. 400-1650 (London, 1952), 274 8; A. R. Hall, The Scientific Revolution 1500-1800: The formation of the modern scientific attitude, 2nd edn (Boston, 1966; orig. publ. 1954), 224-5; H. Butterfield, The origins of modern science 1300-1800, rev. edn (New York, 1965; orig. publ. 1957), 197-8.

13. G. Sarton, The study of the history of mathematics and The study of the history of science (2 vols, bound as 1; New York, 1957; orig. publ. 1936), 15-16. Interestingly, Sarton was here concerned equally to argue against Galois's claim for an internal necessity in the development of mathematics. Insofar as Sarton commended any particular historical attitude it was a particularistic orientation, willing to entertain the role of a range of contingent factors. As Thackray and Merton say, "The emphatic claims for a materialist history of science that enlivened the academic world of the 1930s seem to have meant little to him .... [C] haracteristically, [Sarton] chose not to engage the intellectual issues but to adopt an uneasy imagery in which social and intellectual influences are resisted by the authentic scientists and affect only the 'job-holders"': A. W. Thackray and R. K. Merton, "On discipline building: The paradoxes of George Sarton", Isis, lxiii (1972), 473-95, p. 480; also Cohen, op. cit. (ref. 9), 25-27, 83n-84n. Cf. G. Sarton, A history of science (2 vols, New York, 1970; orig. publ. 1952), i, pp. xii-xiv, where Sarton attempted to dissociate the proper practice of history of science from social and political theorizing of any kind.

14. B. Hessen, "The social and economic roots of Newton's 'Principia", in Science at the cross roads, ed. by N. I. Bukharin, new edition ed. by P. G. Werskey (London, 1971; orig. publ. 1931), 147-212; see also E. Mendelsohn, "Robert K. Merton: The celebration and defense of science", Science in context, iii (1989), 269-89, esp. pp. 273--5. While Hessen's materialism informed his attack on the supposed absolute autonomy of ideas, neither he nor the historical materialist tradition from which he came ever proposed to reduce science totally to its economic foundation: "According to the materialistic conception of history, the final determining factor ... is the creation and recreation of actual life. But this does not mean that the economic factor is the sole determining factor" (Hessen, op. cit. (ref. 14), 177). From Marx and Engels onwards, materialists have always acknowledged that material influences proceed through culture and that cultural practices may come to have relative autonomy. Parenthetically, $\mathrm{e} / \mathrm{i}$ vocabulary was not a pronounced feature of Hessen's essay. A fine appreciation of Hessen and the curious reception of his work is S. Schaffer, "Newton at the crossroads", Radical philosophy, xxxvii (1984), 23-28.

\section{Provided by the NASA Astrophysics Data System}


15. G. Werskey, The visible college: A collective biography of British scientists and socialists of the 1930s (London, 1978); A. Thackray, "History of science", in P. T. Durbin, (ed.), A guide to the culture of science, technology, and medicine (New York, 1980), 3-69, esp. pp. 14-15; J. Ravetz, "Bernal's Marxist vision of history", Isis, lxxii (1981), 393-402.

16. For confirmation of historians' general lack of interest in Hessen's work, see Cohen, op. cit. (ref. 9), 54-60, 84, n. 117. For Sir George Clark's temperate engagement with Hessen's views, eschewing e/i vocabulary, see his Science and social welfare in the age of Newton (Oxford, 1937), ch. 3 ("Social and economic aspects of science").

17. Needless to say, the Left valued science at least as much as the Right, even though the scheme used by Marxists to pour value over science was diametrically opposed to that used by more traditional scholars.

18. See, e.g., J. D. Bernal, The social function of science (London, 1939); J. G. Crowther, The social relations of science (London, 1941), esp. chs 73-77, 81. Crowther informally (p. 511) used the term "external" in reference to social motives for research, drawing a contrast with "personal" motives the most prominent of which is "the desire for understanding for its own sake". See also H. Rose and S. Rose, "The incorporation of science", in idem (eds), The political economy of science (London, 1976), 14-31, where the science policy enterprise is characterized as "pragmatic externalism"; and Schaffer, $o p$. cit. (ref. 14), 23-24.

19. For Michael Polanyi's role in the 1941 Society for Freedom in Science, see Werskey, op. cit. (ref. 15), 281-4, 288-9. The reaction of Karl Popper and Joseph Ben-David to these concerns is also significant for the developing e/i discourse. The lessons drawn in these respects from episodes of Nazi science and, later, Lysenkoist genetics are very well known. It would also be interesting to explore the role of British and American science planning in the Second World War and scientists' post-War reactions to that experience.

20. S. Lilley, "Social aspects of the history of science", Archives internationales d'histoire des sciences, xxviii (1948), 376-443; idem, "Cause and effect in the history of science", Centaurus, iii (1953-54), 58-72. The role of the United Nations, and especially the Commission for the History of the Social Relations of Science, in the emergence of postWar externalism should be explored.

21. A. R. Hall, Ballistics in the seventeenth century (Cambridge, 1952), 162-3. Hall suggested that different disciplines construed scientific change differently. "Sociological history" was here represented by Boris Hessen. The major Marxist-orientated history of science text of the early 1950s (S. F. Mason, A history of the sciences (London, 1953)) weighed in vigorously on the 'craftsman' side of the debate over scientific origins but did not notably deploy e/i vocabulary.

22. B. Barber, Science and the social order (New York, 1962; orig. publ. 1952), 80-81.

23. Ibid., 55, 57-58, 60-61. The view that social factors might influence 'soft' but not 'hard' sciences remained popular at least through the 1970s, inspiring sociologists of scientific knowledge to take on whatever then appeared as 'the hardest case'.

24. R. H. Shryock, "The interplay of social and internal factors in the history of modern medicine", The scientific monthly, lxxvi (1953), 221-30, quoting p. 221. Shryock was evidently already broadly sympathetic to materialist historiography, e.g., idem, "American indifference to basic science during the nineteenth century", Archives internationales d'histoire des sciences, xxviii (1948), 50-65, esp. pp. 59, 62, 64-65.

25. R. H. Shryock, The development of modern medicine: An interpretation of the social and scientific factors involved (Philadelphia, 1936), e.g., pp. vii-viii, 143-8. Shryock reverted to a similar subtitle in his later study of nursing: The history of nursing: An interpretation of the social and medical factors involved (Philadelphia, 1959).

26. Unpublished and undated talk by R. H. Shryock, "Problems in the interpretation of

\section{Provided by the NASA Astrophysics Data System}


American medical history", quoted in W. J. Bell, Jr, "Richard H. Shryock: Life and work of a historian", Journal of the history of medicine, xxix (1974), 15-31, p. 23.

27. Bell, op. cit. (ref. 26), 23. Shryock's Development of modern medicine ((ref. 25), esp. pp. 41, 146-50) displayed basic awareness of Harvard sociological resources, including Pareto and Sorokin.

28. P. P. Wiener and A. Noland (eds), Roots of scientific thought: A cultural perspective (New York, 1957), Part II.

29. A. C. Crombie, "Introduction", in idem (ed.), Scientific change (New York, 1963), 1-11, esp. pp. 3-4.

30. T. S. Kuhn, The structure of scientific revolutions (Chicago, 1962), e.g. pp. xii and note, 68-69, 75, 163-4. Kuhn had tentatively sketched the general form of this scheme in The Copernican revolution: Planetary astronomy in the development of Western thought (Cambridge, Mass., 1959), 123-33, 270-1. And it was elaborated, together with its relation to Mertonian views, in idem, "The history of science", in idem, The essential tension: Selected studies in scientific tradition and change (Chicago, 1977), 105-26 (art. orig. publ. 1968), esp. pp. 118-20.

31. G. Basalla (ed.), The rise of modern science: Internal or external factors? (Lexington, Mass., 1968); also H. F. Kearney (ed.), Origins of the scientific revolution (London, 1964), esp. pp. xi-xv.

32. Kuhn, "History of science" (ref. 30), p. 110. Unlike Rupert Hall, Kuhn saw externalism as a "newer rival" to internalism rather than a dead body. But Kuhn here (p. 113) construed external history broadly as "attempts to set science in a cultural context".

33. Thackray, op. cit. (ref. 15), 15-18; C. C. Gillispie, [art.] "Alexandre Koyré", in Dictionary of scientific biography, vii, 482-90; I. B. Cohen, "The many faces of the history of science", in C. F. Delzell (ed.), The future of history (Nashville, Tenn., 1977), 65-110, pp. 91-93; idem, op. cit. (ref. 9), 61-62; R. Porter, "The history of science and the history of society", in R. C. Olby et al. (eds), Companion to the history of modern science (London, 1990), 3246, pp. 35-36; P. Forman, "Immanence, not transcendence, for the historian of science", Isis, lxxxii (1991), 71-86, pp. 78-79. Note that I have not taken on the task of explaining why historians of science rendered the judgements they did on internalism/externalism, though any such explanation would doubtless have especially to engage with the local political environment of the United States in the 1950s, an environment which, like that of the immediate present, made the distinction between politics and proper intellectual behaviour worryingly problematic. For suggestions along these lines, see A. W. Thackray, "Science: Has its present past a future?", in R. H. Stuewer (ed.), Historical and philosophical perspectives of science (Minnesota Studies in the Philosophy of Science, $\mathrm{v}$; Minneapolis, 1970), 112-33, pp. 116-22.

34. C. C. Gillispie, "Science in the French Revolution", Behavioral science, iv (1959), 67-101; reprinted in The sociology of science ed. by B. Barber and W. Hirsch (New York, 1962), 89-97, p. 89.

35. A. R. Hall, "Merton re-visited or science and society in the seventeenth century", History of science, ii (1963), 1-16, pp. 10-11, 13. In 1968 George Basalla agreed that "the externalists have lost their influence": "Introduction", in idem, op. cit. (ref. 31), pp. viixiv, p. xiii. Professor Hall has been re-visiting Merton from the original 1957 Critical problems conference to the present. Recently his assessment of Merton's work has markedly mellowed, a shift evidently informed by the discovery that there are sociologists about even more threatening than his old antagonist: Hall, "Infant giants are not pygmies: The 'Merton Thesis' and the sociology of science", in J. Clark et al. (eds), Robert K. Merton: Consensus and controversy (London, 1990), 371-83.

36. Lilley, "Cause and effect", 59; see also idem, "Social aspects", 382-4 (both ref. 20), where

\section{Provided by the NASA Astrophysics Data System}


Lilley acknowledged the unique "internal coherence" of science and argued that the "internal order" defined only the necessary but not the sufficient conditions for scientific discovery. For the relations between the "crudeness" of Marxist historiography and the "crudeness" attributed to it, see Schaffer, op. cit. (ref. 14).

37. Hall, op. cit. (ref. 21), 162.

38. H. Guerlac, "Some historical assumptions of the history of science", in Crombie (ed.), op. cit. (ref. 29), 797-812, p. 810.

38. C. E. Rosenberg, "Science and American social thought", in D. D. Van Tassel and M. G. Hall (eds), Science and society in the United States (Homewood, Ill., 1966), 135-62, pp. 160 and 162; see also idem, No other gods: On science and American social thought (Baltimore, 1976), 10.

40. L. Laudan, "Comment" [on Thackray, "Science: Has its present past a future?"], in Stuewer, op. cit. (ref. 33), 127-32, pp. 128-9. The current Laudan now deplores historians' lack of interest in addressing "various theories of scientific change" ("The history of science and the philosophy of science", in Olby, op. cit. (ref. 33), 47-59, p. 52). And for a recrudescence of relaxed anti-theoretical philosophy of science, see A. Fine, The shaky game: Einstein, realism and the quantum theory (Chicago, 1986), 112-50; idem, "Unnatural attitudes: Realist and instrumentalist attachments to science", Mind, xcv (1986), 149-79.

41. R. M. Young, "Malthus and the evolutionists: The common context of biological and social theory", in idem, Darwin's metaphor: Nature's place in Victorian culture (Cambridge, 1985; orig. publ. 1968), 23-55, p. 23.

42. R. M. Young, "The historiographic and ideological contexts of the nineteenth-century debate on man's place in nature", in idem, op. cit. (ref. 41), 164-247 (orig. publ. 1973), p. 177.

43. R. MacCormmach, "Editor's foreword", Historical studies in the physical sciences, i (1969), pp. vii-ix, p. viii. See also idem, ibid., ii (1970), pp. ix-xxiv, esp. pp. ix-x.

44. P. Forman, "Weimar culture, causality, and quantum theory, 1918-1927: Adaptation by German physicists and mathematicians to a hostile intellectual milieu", Historical studies in the physical sciences, iii (1971), 1-115, p. 114.

45. S. Shapin and A. Thackray, "Prosopography as a research tool in history of science: The British scientific community 1700-1900", History of science, xii (1974), 1-28, p. 22, n. 9; B. Barber, "Toward a new view of the sociology of knowledge", in L. A. Coser (ed.), The idea of social structure: Papers in honor of Robert K. Merton (New York, 1975), 103-16, p. 107. $C f$. D. deB. Beaver, "Possible relationships between the history and sociology of science", in J. C. Gaston (ed.), Sociology of science (San Francisco, 1978), 140-61, esp. p. 142.

46. S. Shapin, "The audience for science in eighteenth century Edinburgh", History of science, xii (1974), 95-121, esp. p. 116. Later on, he became bolder and a number of essays on phrenology in Edinburgh sought to show the penetration of 'social influences' into the domain of fact-judgements and observation-reports.

47. S. S. Blume, "Introduction: Sociology of sciences and sociologies of science", in idem (ed.), Perspectives on the sociology of science (New York, 1977), 1-20, p. 12; see also R. Johnston, "Contextual knowledge: A model for the overthrow of the internal/external dichotomy in science", Australian and New Zealand journal of sociology, xii (1976), 193-203; cf. R. Williams and J. Law, "Beyond the bounds of credibility", Fundamenta scientiae, i (1980), 295-315, esp. pp. 296, 305. A canonical anathema pronounced on "doctrinaire" externalism and internalism is J. B. M[orrell], [arts.] "Externalism" and "Internalism", in W. F. Bynum, E. J. Browne and R. Porter (eds), Dictionary of the history of science (London, 1981), 145-6, 211.

48. J. Christie, "The rise and fall of Scottish science", in M. Crosland (ed.), The emergence of 
science in western Europe (London, 1975), 111-26, p. 111. Speech of "intellectualism" and "contextualism" was part of my own attempt to engage with substantive historical issues while avoiding the old usages: S. Shapin, "Social uses of science", in G. S. Rousseau and R. Porter (eds), The ferment of knowledge: Studies in the historiography of eighteenthcentury science (Cambridge, 1980), 93-139.

49. See, esp., R. MacCormmach, "Editor's introduction", Historical studies in the physical sciences, iii (1971), 10: "[disciplines are] a natural unit of study"; "the prevailing institutions and culture affect the scientist's thought and career largely through the mediation of the discipline". Also C. E. Rosenberg, "Toward an ecology of knowledge: On discipline, context, and history", in A. Oleson and J. Voss (eds), The organization of knowledge in modern America, 1860-1920 (Baltimore, 1979), 440-55, p. 441: "specific institutional structures mediate the relationship between men of learning and the society that supports them"; idem, No other gods (ref. 39), 185-6, 209, 214, n. 30; S. G. Kohlstedt, "The nineteenth-century amateur tradition: The case of the Boston Society of Natural History", in G. Holton and W. Blanpied (eds), Science and its public: The changing relationship (Dordrecht, 1976), 173-90, p. 173.

50. Laudan, "The history of science" (ref. 33), 50-51; Cohen, op. cit. (ref. 33), 79. Joseph Agassi did not, I think, greatly clarify the e/i debates with his attempted distinction between "externalism" and "pure externalism": "whereas internal history ignores external factors, external history does not ignore internal factors. Let us label that external history that ignores internal factors 'purely external' so as to keep out much of today's confusion" (J. Agassi, "Externalism", in idem, Science and society: Studies in the sociology of science (Dordrecht, 1981; art. orig. publ. 1978), 55-67, p. 55).

51. C. E. Rosenberg, "Woods or trees: Ideas and actors in the history of science", Isis, lxxv (1988), 565-70, p. 565. Note Mary Hesse's trajectory on these issues over time, from "Hermeticism and historiography: An apology for the internal history of science", in Stuewer, op. cit. (ref. 33), 134-62, to "Reasons and evaluation in the history of science", in M. Teich and R. M. Young (eds), Changing perspectives in the history of science: Essays in honour of Joseph Needham (London, 1973), 127-47, to "The strong thesis of sociology of science", in M. Hesse, Revolutions and reconstructions in the philosophy of science (Brighton, 1980), 29-60, p. 29: "It is now a platitude to hold that the two approaches to the history of science labelled respectively 'internal' or 'rational', and 'external' or 'social' are complementary and not contradictory, and that any so-called conflicts between them are pseudo-conflicts", but $c f$. the old-guard protest by F. Gregersen and S. Køppe, "Against epistemological relativism", Studies in history and philosophy of science, xix (1988), 447-87, p. 453. See also Y. Elkana, "Is there a distinction between external and internal sociology of science?", in R. S. Cohen and T. Schnelle (eds), Cognition and fact: Materials on Ludwik Fleck (Boston Studies in the Philosophy of Science, 1xxxvii; Dordrecht, 1986), 309-16.

52. E.g., T. H. Broman, "J. C. Reil and the 'journalization' of physiology", in P. Dear (ed.), The literary structure of scientific argument: Historical studies (Philadelphia, 1991), 13-42, p. 13; A. Stroup, A company of scientists: Botany, patronage, and community at the seventeenth-century Parisian Royal Academy of Sciences (Berkeley, 1990), 8-10.

53. R. J. Richards, The meaning of evolution: The morphological construction and ideological reconstruction of Darwin's theory (Chicago, 1992), 1-2, 75.

54. B. Barber, Social studies of science (New Brunswick, N.J., 1990), 6-7.

55. C. C. Gillispie, "Scholarship epitomized", Isis, lxxxii (1991), 94-98, p. 97.

56. All positions handled here without attribution can be identified in actual passages of $\mathrm{e} / \mathrm{i}$ debate. It should not escape notice that $I$ appear in this analysis in the character of criticized as well as critic.

\section{Provided by the NASA Astrophysics Data System}


57. See here an hilariously perceptive sketch of the vacuity of much 'factor talk' in M. Lynch, "Pictures of nothing? Visual construals in social theory", Sociological theory, ix (1991), 1-21, pp. 5-6; and, for his unfortunate victim, P. Thagard, "Welcome to the cognitive revolution", Social studies of science, xix (1989), 653-7, esp. Fig. 1 (for a "sensible" eclectic picture of the roles of "cognitive" and "social factors").

58. Technically, one could continue to theorize about scientific change, as a sub-species of fully general theories of cultural change, but few participants in the e/i debates have shown any inclination to make that move.

59. Or incorporating yesterday's extrinsic into today's intrinsic - ideally by an effortless display of its all-along appropriateness. $C f$. Paul Feyerabend's critique of Lakatosian distinctions between 'external' and 'internal' in Feyerabend, Against method (London, 1978; orig. publ. 1975), 211, where he notes that the construction of a methodologically coherent 'internal history' may only be possible because its " 'external' history contains compensating actions that violate the defining methodology at every turn". Citing Galilean examples, he argues that "agreement 'inside' science is the result of numerous violations 'outside' of it", and that, insofar as these 'external violations' were necessary for the cultural change celebrated by Lakatos's 'internal history', "they therefore belong to science itself'.

60. Historical work from the 1960s claiming non-scientific (magical, religious, hermetic, and otherwise 'irrational') influences upon early modern science was a notable locus for these confusions.

61. In this tradition it has been claimed, for example, that social influences work most strongly when actors are 'least conscious' of them. Here and elsewhere it is remarkable that history of science debates have been so uninformed by parallel issues in the historiography of political thought since the 1960s. I have specifically in mind Quentin Skinner's historicist contextualism and his powerful criticisms of 'influence' models: e.g., J. Tully (ed.), Meaning and context: Quentin Skinner and his critics (Oxford, 1988).

62. An attempt to identify some problems bearing upon historians' motive-ascription is B. Barnes and S. Shapin, "Darwin and Social Darwinism: Purity and history", in idem (eds), Natural order: Historical studies of scientific culture (Beverly Hills, Calif., 1979), 95-121.

63. Merton's 'other' thesis (about the effect of economic needs upon scientific foci of interest) is an example of social structural analysis while his "Puritanism and science" thesis invoked individuals' motivational states.

64. My own research through the mid-1970s mostly answered to this description. We owe our increasing recognition of the analytic distinction between the 'social' and the 'external' largely to Barry Barnes, H. M. Collins, and Bruno Latour.

65. S. Shapin, "The mind is its own place': Science and solitude in seventeenth-century England", Science in context, iv (1991), 191-218; see also J. Agassi, "Towards an historiography of science", History and theory, 1963, Beiheft 2.

66. E.g., H. Putnam, "The meaning of 'meaning'", in idem, Mind, language and reality (Philosophical papers, ii; Cambridge, 1975), 215-71; P. Kitcher, "Theories, theorists and theoretical change", Philosophical review, lxxxvii (1978), 519-47; idem, "The division of cognitive labor", Journal of philosophy, lxxxvii (1990), 5-22. And for a thoroughly naturalistic account of rationality, see B. Barnes, "Natural rationality: A neglected concept in the social sciences", Philosophy of the social sciences, vi (1975), 115-26.

67. D. MacKenzie and B. Barnes, "Scientific judgment: The biometry-Mendelism controversy", in Barnes and Shapin, op. cit. (ref. 62), 191-210, esp. p. 205. This is one of several quite fundamental features of recent work in the sociology of scientific knowledge missed by $\mathbf{R}$. J. Richards, op. cit. (ref. 53), 1, who ridicules writers supposedly invoking "class jealousies and the kind of Molièrean interests that seem to explain everything".

\section{Provided by the NASA Astrophysics Data System}


68. B. Barnes, Scientific knowledge and sociological theory (London, 1974), ch. 5.

69. See also the symbolic interactionist perspective on change and consistency in individual careers: e.g., H. S. Becker, "Notes on the concept of commitment", American journal of sociology, lxvi (1960), 32-40.

70. S. Shapin, "History of science and its sociological reconstructions", History of science, $\mathbf{x x}$ (1982), 157-211, esp. pp. 177-8, 194-8; see also idem, "Science and the public", in Olby et al. (eds), op. cit. (ref. 33), 990-1007.

71. S. Shapin and S. Schaffer, Leviathan and the air-pump: Hobbes, Boyle, and the experimental life (Princeton, 1985), 342. Sociological work exploring an actor-orientated instrumental approach to scientific boundaries includes: P. E. G. Wright, "Astrology and science in seventeenth-century England", Social studies of science, v (1975), 399-422; idem, "On the boundaries of science in seventeenth-century England", in E. Mendelsohn and Y. Elkana (eds), Sciences and cultures (Sociology of the sciences yearbook, 1981; Dordrecht, 1981), 77-100; H. M. Collins and T. J. Pinch, "The construction of the paranormal: Nothing unscientific is happening", in R. Wallis (ed.), On the margins of science: The social construction of rejected knowledge (Sociological review monographs, no. 27; Keele, 1979), 237-69; H. M. Collins, "Public experiments and displays of virtuosity: The core-set revisited", Social studies of science, xviii (1988), 725-48; S. S. Jasanoff, "Contested boundaries in policy-relevant science", ibid., xvii (1987), 195-230; T. F. Gieryn, "Boundary-work and the demarcation of science from non-science: Strains and interests in the professional ideology of scientists", American sociological review, xlviii (1983), 781-95; idem, "Distancing science from religion in seventeenth-century England", Isis, lxxix (1988), 582-93, esp. p. 590; idem, "Boundaries of science", in S. S. Jasanoff et al. (eds), Handbook of science, technology and society, forthcoming [kindly sent to me by the author after this paper was completed, it is a useful synthetic review of relevant recent work]; D. Fisher, "Boundary work and science: The relation between power and knowledge", in S. E. Cozzens and T. F. Gieryn (eds), Theories of science in society (Bloomington, Ind., 1990), 98-119; S. L. Star and J. R. Griesemer, "Institutional ecology, 'translations' and boundary objects: Amateurs and professionals in Berkeley's Museum of Vertebrate Zoology, 1907-39", Social studies of science, xix (1989), 387-420; and, closest to the present argument, A. Pickering, "Big science as a form of life", in M. De Maria, M. Grilli, and F. Sebastiani (eds), Proceedings of the International Conference on the Restructuring of Physical Sciences in Europe and the United States 1945-1960 (Singapore, 1989), 42-54. Schaffer and I have continued to work in this idiom. Other recent historical work on the creation and maintenance of social and cultural boundaries in science includes: P. Dear, "Miracles, experiments, and the ordinary course of nature", Isis, lxxxi (1990), 663-83; J. V. Golinski, "A noble spectacle: Research on phosphorus and the public cultures of science in the early Royal Society", ibid., lxxx (1989), 11-39; D. Gooding, "'In nature's school': Faraday as an experimentalist", in idem and F. A. J. L. James (eds), Faraday rediscovered: Essays on the life and work of Michael Faraday, 1797-1867 (London, 1985), 106-35; R. C. Iliffe, "The idols of the temple': Isaac Newton and the private life of anti-idolatry" (Ph.D. thesis, Cambridge University, 1989); idem, " 'In the warehouse': Privacy, property and priority in the early Royal Society", History of science, xxx (1992), 29-68; R. S. Westman, "The astronomer's role in the sixteenth century: A preliminary study", ibid., xviii (1980), $105-47$.

72. A synthetic source is B. Latour, Science in action: How to follow scientists and engineers through society (Milton Keynes, 1987).

73. B. Latour, "Mixing humans and nonhumans together: The sociology of a door-closer", Social problems, xxxv (1988), 298-310; idem, "Postmodern? No, simply amodern! Steps towards

\section{Provided by the NASA Astrophysics Data System}


75. Latour, op. cit. (ref. 72), e.g., pp. 62, 127, 140, 240. It is unclear how speech of "networks" or "stronger and weaker heterogeneous associations" is supposed to be immune from the criticisms that ban "science" and "society".

76. Paul Forman has recently and passionately (op. cit. (ref. 33), 78) renewed the plea for independence for the historian of science, though his programme for how this might be accomplished will come as a major surprise to practitioners who think that this is what they have been doing for many years: "Only by thoroughly historicizing scientific knowledge - explaining possession of specific pieces or structures of it, not by appealing to a transcendent reality ..., but by reference to mundane factors and human actors can historians of science move away from whiggery and toward intellectual independence."

77. Needless to say, this would not be a prudent course if we were seeking to write for an audience of seventeenth-century divines.

78. For germane philosophical treatment of weak, ineliminable, and historiographically innocuous presentism, see G. L. Hardcastle, "Presentism and the indeterminacy of translation", Studies in history and philosophy of science, xxii (1991), 321-45; cf. D. Hull, "In defense of presentism", History and theory, xviii (1979), 1-15, esp. pp. 4-5: "Histories are written not only by people and about people but also for people."

\section{Provided by the NASA Astrophysics Data System}

